$12-21-2020$

\title{
Democratization as a Protective Layering for Crimes Against Humanity: The Case of Myanmar
}

Anna B. Plunkett

King's College London

Follow this and additional works at: https://digitalcommons.usf.edu/gsp

\section{Recommended Citation}

Plunkett, Anna B. (2020) "Democratization as a Protective Layering for Crimes Against Humanity: The Case of Myanmar," Genocide Studies and Prevention: An International Journal: Vol. 14: Iss. 3: 69-89. DOI:

https://doi.org/10.5038/1911-9933.14.3.1718

Available at: https://digitalcommons.usf.edu/gsp/vol14/iss3/8

This Articles is brought to you for free and open access by the Open Access Journals at Digital Commons @ University of South Florida. It has been accepted for inclusion in Genocide Studies and Prevention: An International Journal by an authorized editor of Digital Commons @ University of South Florida. For more information, please contact digitalcommons@usf.edu. 
Democratization as a Protective Layering for Crimes Against Humanity: The Case of Myanmar

\section{Acknowledgements}

The author would like to thank King's College London and the ESRC for their funding and support of this work as part of the wider PhD project. 


\title{
Democratization as a Protective Layering for Crimes Against Humanity: The Case of Myanmar
}

\author{
Anna B. Plunkett \\ King's College London \\ London, UK
}

\section{Introduction}

Since Myanmar's independence, the borderlands have been characterized by periodic and cyclical violence as ethnic armed organizations (EAOs) have fought against state military offensives. Despite the evident asymmetry between the well-equipped and extensive Tatmadaw and the many rebel groups that remain, at least to some degree, poorly organized and underfunded, war has plagued the borderland communities since independence. ${ }^{1} \mathrm{~A}$ barrage of human rights abuses has come in the wake of the low-intensity, long-term war, waged by the Tatmadaw who have historically viewed civilian populations with suspicion and often as acceptable collateral damage. Such a precedent as this has been accepted whilst the military dominated the state during the period of the military junta. However, as Myanmar has begun its transition towards a seemingly democratic state, with the triple transition process, there has been a fall in the levels of direct violence experienced within the borderlands. ${ }^{2}$ Whilst this could be considered a positive development, this paper will question the authenticity of these changes. Though direct violence has reduced, forms of indirect violence and crimes against humanity have continued. Transition has not ended state sponsored violence but rather transformed it. As such, there has not been an end to the crimes against humanity for these communities, but rather the mechanisms by which it is conducted have transformed over time.

The first part of this paper will focus on actions against the minority communities within Myanmar's borderlands as enacted under the military junta between 1962 and 2008. ${ }^{3}$ It will identify how key events changed the relations between the military and these local populations, including the introduction of the Four Cuts strategy, the major offensives of the 1980s and the ceasefire agreements of the 1990s. The second part will identify how the triple transition introduced to Myanmar in 2008, and led by the military, has and has not altered the actions of the military and their engagements with local communities within the borderlands. ${ }^{4}$ The final section will focus on how the process of the triple transition has transformed the methods used to continue the violence and marginalization of these populations within the

1 The Tatmadaw is the title of the Myanmar military forces. Here, the two terms Tatmadaw and military will be used interchangeably.

2 Within this paper the author will refer to the country before 2008 as Burma and in the post-2008 period as Myanmar. Although the name was officially changed during the 1989 change of government, it was not widely accepted prior to the transition period which began in 2008. This does not reflect the personal views of the author or her participants or identify any preference or support for differing groups within the country. The triple transition process in Myanmar was identified and outlined by The World Bank in 2012 as part of their interim strategy for working in Myanmar. See "World Bank Prepares Interim Strategy Note for Myanmar," World Bank, August 10, 2012, accessed October 5, 2020, http:// www.worldbank.org/en/news/feature/2012/08/10/world-bank-preparesinterim-strategy-note-for-myanmar.

${ }^{3}$ Though this period includes several differing formations of the Burmese state including a military junta, one-party state, and a socialist regime, all of these regimes have been dominated by the military at almost all levels of governance. Therefore, the similarities between such regime types and governance models provide strong grounds for analysing them together under one time period.

${ }^{4}$ This section will draw on evidence from the Karen and Kachin experiences, in line with the field research completed by the author. It is not to suggest that this is a universal experience to all borderland communities within Myanmar but exemplifies some of the common experiences communities have and continue to face along the frontlines between the EAOs and Tatmadaw. 
borderlands. ${ }^{5}$ This article will build on research and insights collected by the author on several research trips to the areas under study and with activists working inside Myanmar from along the Thai-Burma border. By engaging with local perspectives on the continuing human rights situation along the border, the article is able to move beyond national and internal rhetoric on transition and democratization that has too often been the foci of international engagement within Myanmar since 2015.

Myanmar's government and military have faced myriad threats from ethnic oppositions, and most recently have been implicated in an ongoing genocide in Rakhine against the Rohingya people. ${ }^{6}$ Not to minimize the scale and devastation of the plight of the Rohingya, the oppression they face from the state both in terms of conduct and reasons for such oppression present an anomaly in relation to historic state policy. As such, this paper focuses not on the Rohingya crisis but the experiences of other ethnic groups within the borderlands, particularly the Karen and Kachin communities based in the east and north of the country, who have experienced a process of slow genocide since independence. Both these ethnic groups have faced systematic oppression and been victim to crimes against humanity. Though, at times these experiences have diverged, there is great commonality between their experiences when they are viewed over time. ${ }^{7}$ The Karen and Kachin have mounted large-scale rebellions against the state with popular support from their home communities. Though their experiences do not match every minority group within Myanmar, nor does the experience detailed below represent all of those within each of these communities, their more comprehensive organization and international outreach has provided an insight into these regions and communities that have long been neglected.

\section{Burma Under the Military 1962-2008}

When Burma was granted independence by the British colonial powers in 1948, it was already a state in crisis. War ravaged Burma had witnessed several brutal fronts during World War II as well as two separate occupying forces and numerous bombardments from air and ground troops. ${ }^{8}$ Though desired, independence did not bring peace to Burma, with the assassination of the country's leader, Aung San and his cabinet occurring just before the historic handover. ${ }^{9}$ Factionalism plagued not only the cabinet but across the country, with mounting insurgencies from both communist and ethnic cleavages. Consequently, the military staged a coup d'état in 1962 with the aim of unifying both the government and the country. This responsibility has become institutionalized within the Tatmadaw, who, at their core believe their role is to maintain the territoriality of the Union and protect it above all else. ${ }^{10}$

\footnotetext{
${ }^{5}$ It is important to note that there is debate on how independent the institutions of state and military are within Myanmar given the transition that has been ongoing since 2008. As this paper focuses on state-sponsored violence and the use of soft as well as coercive power, it accepts the premise that though these institutions are separate, it is almost impossible to distinctly separate their actions within this environment.

6 Maung Zarni and Alice Cowley, "The Slow-Burning Genocide of Myanmar's Rohingya," Pacific Rim Law E Policy Journal 23, no. 3 (2014), 746-751.

${ }^{7}$ For in-depth insight into these states experiences over time, see Daniel Pedersen, Secret Genocide: Voices of The Karen Of Burma, (Dunboyne: Maverick House, 2011); Mandy Sadan, ed., War and Peace in the Borderlands of Myanmar: The Kachin Ceasefire, 1994-2011 (Copenhagen: NIAS Press, 2016); David Brenner, Rebel Politics: A Political Sociology of Armed Struggle in Myanmar's Borderlands (Ithaca: Cornell University Press, 2019).

${ }^{8}$ Mary P. Callahan, Making Enemies: War and State Building in Burma (Ithaca: Cornell University Press, 2005), 46-51; Jared Downing, "Myanmar 101: Burma in World War II," Frontier Myanmar, June 19, 2017, accessed December 3, 2020, https://www.frontiermyanmar.net/en/myanmar-101-burma-in-world-war-ii/.

9 Andrew Selth, “Burma: A Strategic Perspective,” Working Paper Series (Japan: The Asia Foundation, May 2001).

10 Renaud Egreteau, Caretaking Democratization: The Military and Political Change in Myanmar (London: C Hurst \& Co., 2016); Melissa Crouch, The Constitution of Myanmar: A Contextual Analysis, 1st ed. (Oxford: Hart Publishing, 2019), 37-39; Andrew Selth, "All Going According to Plan?: The Armed Forces and Government in Myanmar," Contemporary Southeast Asia: A Journal of International and Strategic Affairs 40, no. 1 (April 2018), 1-26.
} 
The Tatmadaw solidified their role as state leaders through the 1974 adoption of the "Burmese Way to Socialism," which saw Burma isolate itself from the international stage. This policy of isolationism ruined Burma's economy, going from one of the fastest growing Asian Tigers to applying for Least Developed Country Status (LDC) in 1987.11 Though devastating for Burma's peasant population throughout the country, the borderland communities found themselves in an even more precarious position.

Thirty years of Burmese independence had resulted in 30 years of war within the borderlands. The mountainous jungle terrain and asymmetrical power structures between the Tatmadaw and EAOs forced the latter to adopt guerrilla tactics, entrenching conflict as part of daily life and blurring the lines between armed groups and civilians. This entanglement of civilian and rebel life was identified by the state and became the target of the Four Cuts counterinsurgency policy adopted during the 1960s. ${ }^{12}$ It aimed to remove the four supply lines EAOs required for survival: food, funds, recruits and intelligence. ${ }^{13}$ Yet, the implementation treated civilian communities as collateral damage with tactics including mass forced relocation, razed villages and farm-holds, the widespread use of landmines as well as systematic arrest and torture policies. ${ }^{14}$ This was in addition to restrictions and hardships that communities faced because of the war, such as arbitrary arrests, forced portering, illegal torture and execution as well as rape of women and children. Further, discriminatory state policies failed to protect other minority rights, such as the lack of official recognition of minority languages and culture in favor of the Barmar majority cultural and religious signifiers. ${ }^{15}$ Communities in the borderlands faced three overlapping types of state oppression during this period: direct violence (as a consequence of the war); violence as a consequence of state sanctioned counter-insurgency strategies; and oppression of cultural norms and rights through the prioritization of the Barmar identity.

This peaked in the mid-1980s when the violence leveled against the Karen population drove thousands across the border to Thailand. By the end of the junta period, such refugees and displaced people officially numbered over 150,000 along several camps on the Thai-Burma border. ${ }^{16}$ In part, this increase is related to the decision by the central command to force Tatmadaw battalions within the borderlands to "live off the land." 17 This policy saw the central government and military cease funds for supplies to their battalions, forcing them to extract it from the civilian population. In the borderlands, where the Tatmadaw were perceived as an invading force, there was little to no civilian support for these battalions. ${ }^{18}$ Consequently, to survive, battalions committed further abuses against civilian communities, confiscating their food supplies, stores, livestock, and equipment as required, often razing villages or killing

11 Lowell Dittmer, "Burma vs. Myanmar: What's in a Name?," in Burma or Myanmar? The Struggle for National Identity, ed. Lowell Dittmer. (World Scientific, 2010), 1-20.

12 Karen Human Rights Group (KHRG), Foundation of Fear: 25 Years of Villagers' Voices from Southeast Myanmar (Myanmar: Karen Human Rights Group, October 2017), 23-24, accessed October 13, 2020, https://reliefweb.int/report/ myanmar/foundation-fear-25-years-villagers-voices-southeast-myanmar.

13 Pedersen, Secret Genocide, 8-9, 50.

14 KHRG, Foundation of Fear, 38-63.

15 Marie Lall and Ashley South, "Comparing Models of Non-State Ethnic Education in Myanmar: The Mon and Karen National Education Regimes," Journal of Contemporary Asia 44, no. 2 (April 3, 2014), 304, accessed October 13, 2020, https:// doi.org/10.1080/00472336.2013.823534.

16 KHRG, Foundation of Fear, 24-25.

17 "Guns, Cronies and Crops: How Military, Political and Business Cronies Conspired to Grab Land in Myanmar," Global Witness, March 26, 2015, accessed November 15, 2020, https://www.globalwitness.org/en/campaigns/landdeals/guns-cronies-and-crops/.

18 Stephen Hull, “The 'Everyday Politics' of IDP Protection in Karen State," Journal of Current Southeast Asian Affairs 28, no. 2 (July 29, 2009), 12. 
community leaders to eliminate any evidence. ${ }^{19}$ In this period, communities in the borderlands faced an additional threat to the lives and livelihoods from the military and they became victims not only to counter-insurgency policies but over direct competition for resources.

Though a number of ceasefires were signed in the early 1990s, including in Kachin State, conflict continued in Karen. Unable to reach an agreement with the Karen National Union (KNU), the Tatmadaw launched increasingly ferocious offensives against key locations within Karen and other regions under the control of KNU forces. This included their capital and headquarters Mannerplaw, which had grown to be an oasis for pro-democratic forces from all parts of Burma. ${ }^{20}$ Consequently, communities in Karen continued to experience the denial of their rights and structural insecurities from the ongoing conflict, counterinsurgency and other government policies, as well as the lack of official recognition of the cultural rights.

Whereas the Kachin Independence Organization (KIO) signed a ceasefire with the government in the 1990s, though this did not necessarily protect local populations from crimes committed by the state. As Sadan's work on the second Kachin ceasefire highlights, in the 17 years of "peace" created by the 1994 agreement, the population still faced high levels of militarization and remained vulnerable to abuses. ${ }^{21}$ The military government pursued aggressive investment strategies within the region, often in areas not under their own control..22 This gave the military remit to enter such areas to secure locations for development whilst further cutting the KIO off from their own territories and traditional revenue streams. ${ }^{23}$ For civilian populations, this meant vulnerability to forced relocations, forced labor, and confiscation of resources as battalions were and remain under instruction to live off the land. Thus, despite the presence of ceasefires in some borderland regions, communities remained vulnerable to state violence and oppression as they were within the conflict regions.

Under military control, the ethnic minorities in Burma's resource rich borderlands have experienced systematic human rights abuses that amount to crimes against humanity. The forced relocation of 100,000's of people remains the clearest reminder of this. However, restrictions on cultural and religious freedoms of these communities, the cyclical violence they have faced, and the removal of livelihoods and ways of life have culminated in much wider reaching implications for these communities who feel their whole way of life and existence has been under threat.

\section{Myanmar and the Triple Transition: A Work in Progress}

The acceptance of the 2008 Constitution started a process that would become known as the triple transition in Myanmar. ${ }^{24}$ The document itself set out the institutional changes and structure of what political transition the country would take. It further outlined an economic plan for market liberalization, ending the state-centric policies of the socialist and junta eras. To achieve the institutional frameworks and goals set out within it, the need to further transition from war to peace was clearly underscored. Myanmar's triple transition had begun.

At the institutional and macro-conception, regime transition in Myanmar has progressed smoothly, achieving successive goalposts in its quest to democratize. Though the progress toward regular institutional elections may have been achieved, the representativeness

19 Neil A. Englehart, "Is Regime Change Enough for Burma? The Problem of State Capacity," Asian Survey 45, no. 4 (August 2005), 638, accessed November 15, 2020, https:/ / doi.org/10.1525/as.2005.45.4.622; Hull, Everyday Politics, 12.

20 Pedersen, Secret Genocide, 8-9, 50-51.

21 Sadan, War and Peace.

22 Interview Kachin Activist, interview by Author, Face to Face, Chiang Mai, June 17, 2018.

${ }^{23}$ Lee Jones, "Understanding Myanmar's Ceasefires: Geopolitics, Political Economy and State-Building," in War and Peace in the Borderlands of Myanmar: The Kachin Ceasefire, 1994-2011, ed. Mandy Sadan (Copenhagen: NIAS Press, 2016), 100.

24 Zhentu Liu, "Tracking Myanmar's Public Procurement Reform," World Economic Forum, February 9, 2015, accessed October 13, 2020, https:/ / www.weforum.org/agenda/2015/02/tracking-myanmars-public-procurement-reform/. 
of the governments it elects are suspect. The military continue to hold twenty-five percent of seats within government and held onto core positions and ministries within the new government. Further, both elections since 2008 have missed areas deemed too unsafe or unstable for them to be conducted. ${ }^{25}$ Demonstrably, the military may have stepped back from day to day governance, but they have chosen to remain a shadow in the halls of government, poised to tackle any deemed threat to Myanmar's development.

Beyond the institutional structures, transition to democracy leaves much to be desired for local communities. Many in Myanmar continue to struggle to access their political and human rights along with the resources to fulfil their basic needs. Those living in conflict zones in Shan, Karen, and Kachin have been denied voting rights in elections. ${ }^{26}$ Most notably the Rohingya in Rakhine were denied the right to vote in 2015 with no national parties fielding any Muslim candidates. ${ }^{27}$ This electoral marginalization has contributed to the mounting oppression of rights minorities within the borderland already face.

When President Thein Sein took office in 2010, there was fear that little would change given his military ties. On the contrary, he oversaw a period of dramatic reform focusing on the overdue economic liberalization of Myanmar. Under his leadership, the country saw major increases in development aid and Foreign Direct Investment (FDI) to help improve infrastructure and harvest many of Myanmar's rich natural resource deposits. ${ }^{28}$ International funders arrived, buoyed by the belief that economic transition would aid Myanmar's political and conflict transitions. Yet, they were also pulled by the rich investment opportunities from large-scale infrastructure projects, including deep seaports and new railroads, to resource rich lands that include precious stones, oil, and teak. Alterations to the rules governing FDI in Myanmar, along with increased length of land leases to foreigners broke down many of the boundaries investors had previously faced.29 This resulted in an unprecedented wave of FDI to Myanmar in 2010.30

The establishment of the National Ceasefire Agreement (NCA) was the last act of Thein Sein's government and the first multilateral ceasefire ever secured within the country. This ended much of the direct violence that had characterized the borderlands since independence, including the solidification of the peace between the KNU and the government, suspending the world's longest civil war. ${ }^{31}$ Although direct violence was suspended, the lack of compromise between the EAOs and the Tatmadaw resulted in only the preliminary agreement being signed. This has led many to note the agreement is "surface only" and that the complex framework that

25 Ye Mon, “UEC Cancels Voting in Two More Shan Townships," The Myanmar Times, October 28, 2015, accessed October 13, 2020, https://www.mmtimes.com/national-news/17226-uec-cancels-voting-in-two-more-shantownships.html; Jack Davies and Matthew Weaver, "Burma Election Turnout Remains Low," The Guardian, November 7, 2010, accessed October 13, 2020, https://www.theguardian.com/world/2010/nov/07/burmaelection-turnout-low.

26 “Myanmar Election: Suu Kyi's NLD Wins Myanmar Landslide,” BBC, November 13, 2015, accessed October 13, 2020, http://www.bbc.co.uk/news/world-asia-34805806.

27 Poppy McPherson, “No Vote, No Candidates: Myanmar's Muslims Barred from Their Own Election," The Guardian, November 3, 2015, accessed October 13, 2020, https://www.theguardian.com/world/2015/nov/03/no-vote-nocandidates-myanmars-muslims-barred-from-their-own-election.

${ }^{28}$ Soe Zeya Tun, "Myanmar Signs Ceasefire to End 62-Year Ethnic Conflict," Reuters, January 12, 2012, accessed October 13, 2020, https: / / www.reuters.com/article/ us-myanmar-ethnic-idUSTRE80B0EX20120112.

29 Anders Engvall and Soe Nandar Linn, "Myanmar Economic Update: Macro-Economy, Fiscal Reform, and Development Options," in Debating Democratization in Myanmar, ed. Nick Cheesman et al. (Singapore: ISEAS Publishing, 2014), 162, https://doi.org/10.1355/9789814519151-015; See also Sean Turnell, "Burma's Economic Transition: Hopes and Hurdles," Social Research 82, no. 2 (Summer 2015), 492.

30 Khin Maung Nyo, “Taking Stock of Myanmar's Economy in 2011," in Myanmar's Transition: Openings, Obstacles and Opportunities, ed. Nick Cheesman et al. (Singapore: ISEAS Publishing, 2012), 121, https://doi.org/ $\underline{10.1355 / 9789814414173-014 .}$.

31 Ashley South, "Burma's Longest War: Anatomy of the Karen Conflict," Special Reports (Amsterdam: Transnational Institute, March 2011), 6, accessed December 3, 2020, https://www.tni.org/en/briefing/burmas-longest-waranatomy-karen-conflict. 
has been built around the NCA is there to ensure the military advantage at every stage. ${ }^{32}$ This, in itself, was reminiscent of the previous bilateral ceasefires which were more akin to business transactions, suspending direct violence for economic gain than a substantial commitment to the peace process they were trying to emulate. ${ }^{33}$

Peace and reconciliation were placed at the top of the National League for Democracy's (NLD) priorities when they took office in 2015.34 Yet, it was the military negotiators that maintained the major role within the peace talks, with the government taking on the role of mediators. ${ }^{35}$ Despite increasing the number of talks and peace conferences, little has been achieved in terms of results for Myanmar's peace process. In 2018, hope seemed to arise as two new groups joined the agreement, yet this was soon dashed by inter-signatory clashes. ${ }^{36}$ Concerns increased later that year when the KNU and Restoration Council of Shan State (RCSS), two of the largest groups within the NCA, decided to suspend their membership after a number of confrontations with Tatmadaw in EAO defined territory. ${ }^{37}$ Though the final cause of suspension, the incursions were not the sole reason for this decision. Both groups publicized frustrations with the peace process and cited the government and the military's unwillingness to compromise, as well as the establishment of new preconditions they had been expected to sign before negotiations could continue. ${ }^{38}$ This has reflected growing frustrations with the peace process which for those involved has lacked the necessary compromise on both sides to progress effectively. ${ }^{39}$

The common obstacle to effective change is the role of the military within transitional processes. The military holds its allocated seats and sections within the political arena and is able to override many government decisions with little established transparency to hold them accountable for their interventions. Though officials seated in the military blocks of each of the houses have shown surprising independence and engagement with parliamentary process, on several occasions, the military's ability to override political process has been obvious. ${ }^{40}$ Most notably, under Thein Sein, the government announced a ceasefire with the KIO, only to have the Tatmadaw completely ignore the government directive. ${ }^{41} \mathrm{It}$ is this notion of elevated importance that permits the military to act outside the law without impediment. Although the NCA has reduced the levels of direct violence in many areas of the borderlands, the military continue to wage war against non-NCA signatories. As identified by Jones, under the Kachin ceasefire

32 Yangon Based Karen Community Leader, Interview by Author, Face to Face, Mae Sot, December 12, 2018; Member of Karen Refugee Council, Interview by Author, Face to Face, Mae Sot, December 12, 2018; Kachin Women's Rights Activist, Interview by Author, Face to Face, Chiang Mai, June 18, 2019; Ceasefire Official, Interview by Author, Face to Face, Chiang Mai, November 9, 2018.

33 Paul Core, "Burma/Myanmar: Challenges of a Ceasefire Accord in Karen State," Journal of Current Southeast Asian Affairs 28, no. 3 (October 27, 2009), 99-100; Min Zaw Oo, “Understanding Myanmar's Peace Process: Ceasefire Agreements," Catalizing Reflection 2 (Myanmar: Swisspeace, 2014), 8, accessed December 3, 2020, https:// www.swisspeace.ch/fileadmin/user upload/Media/Publications/Catalyzing_Reflections 2 2014 online.pdf.

34 Thu Thu Aung, "NLD Reaffirms Priorities of Peace and Reconciliation," The Irrawaddy, September 27, 2017, accessed October 15, 2020, https:/ / www.irrawaddy.com/news/burma/nld-reaffirms-priorities-peace-reconciliation.html.

35 Ceasefire Official, Interview by Author, Face to Face, Chiang Mai, June 28, 2019.

36 Anna Plunkett, “A Glimmer of Hope for Burma's Peace Process?," Strife (blog), 2018, accessed October 15, 2020, http://www.strifeblog.org/2018/03/27/a-glimmer-of-hope-for-burmas-peace-process/.

37 Nyein Nyein, “Analysis: Why Did the KNU Temporarily Leave Peace Talks?," The Irrawaddy, October 29, 2018, accessed October 15, 2020, https:/ / www.irrawaddy.com/ factiva/ analysis-knu-temporarily-leave-peace-talks.html.

38 Lun Min Mang, “Dismay over NCA-Signatories Growing," The Myanmar Times, January 12, 2018, accessed October 15, 2020, https://www.mmtimes.com/news/dismay-over-nca-signatories-growing.html.

${ }^{39}$ Field Research Interviews, Interviews conducted by Author, Face to Face, Thailand and Myanmar, June 2018-2019.

40 Renaud Egreteau, "Patterns of Military Behavior in Myanmar's New Legislature," Asia Pacific Bulletin, No. 233 (Washington D.C.: East-West Center, September 24, 2013).

41 Ashley South, "Protecting Civilians in the Kachin Borderlands, Myanmar: Key Threats and Local Responses," (Humanitarian Policy Group (HPG) Working Paper 4, Overseas Development Institute, London, 2018), 4, accessed October 15, 2020, https:// www.odi.org/sites/odi.org.uk/ files/resource-documents/12566.pdf. 
which ended in 2011, the military continued to pursue control of land and communities held by EAOs through other means..$^{42}$ The use of economic development and infrastructure projects as a mechanism to permit the military to enter, secure, and control territory identified as under EAO control has become a preferred strategy of the military. ${ }^{43}$ With the 2011 ceasefire breakdown occurring over a military outpost adjacent to one of the major dam projects along the KachinChina border. ${ }^{44}$ This created localized escalations in violence, including the forced relocation of local communities either in the name of development or due to mistrust of the military. There are now over 100,000 displaced people in Kachin State and along the China border. ${ }^{45}$ Thus, the presence of ceasefire did not alleviate the threat to society of slow genocide but rather altered the methods to which it is being conducted.

Yet, direct or indirect violence are not the only methods of dispossession employed by the state and military in relation to minority communities. Many communities in the borderlands still face issues accessing justice and state services with many identifying increasing crackdowns on their freedom of expression since 2015. There are three main reasons for this. First, in conflict areas, justice is difficult to achieve as often, would be cases are resolved directly between perpetrators and victims and involve a fiscal settlement, rather than an attempt to achieve justice. ${ }^{46}$ Second, should any case involve the military, the Tatmadaw will ensure that it is heard in a military court where family and local leaders must gain permission to attend and there is less accountability. ${ }^{47}$ In both these instances, though a form of resolution may be offered to victims, there is a lack of accountability and transparency that leaves victims and their families vulnerable to further intimidation and injustices. Yet, on the few times cases do make it to civilian courts, there remains no guarantee of transparency or accountabilityover fifty percent of judges have a military background in Myanmar, including both the Chief Justice and the Attorney General. ${ }^{48}$ Further, all cases are heard in Burmese and although under the law all minorities speakers may have a translator, many are not aware of their rights and so remain vulnerable within the justice system. ${ }^{49}$ Thus, justice remains inaccessible to many.

Yet, institutional obstacles are not the only barriers ethnic minority communities face in achieving justice for crimes committed against them. Traditional customs and cultural practices have also prevented victims from seeking justice. There is a saying in relation to Myanmar's legal practice - "Keep the cases small, and make small cases disappear," which is equivalent to - "do not air your dirty laundry." 50 It discourages victims from coming forward, which is already an issue due to the institutional, financial, and accessibility barriers minority communities already face in accessing justice in Myanmar. Further, the increasing use of new laws to prosecute individuals criticizing the government has resulted in law being viewed as a tool of oppression rather than one of liberation. This is particularly in reference to the use of $66 \mathrm{~d}$, a telecommunications law, which has been levied against numerous human rights

\footnotetext{
42 Jones, Understanding Myanmar's Ceasefires, 104-105.

${ }^{43} \mathrm{Su}-\mathrm{Ann} \mathrm{Oh}$, "Competing Forms of Sovereignty in the Karen State of Myanmar," (Singapore: ISEAS Working Paper No. 1, 2013), 10.

${ }^{44}$ Ye Mon, Thomas Kean, and Hkun Lat, "War and Business: Kachin's 'Frontline' Hydropower Dam," Frontier Myanmar, July 29, 2019, accessed October 15, 2020, https:/ / pulitzercenter.org/reporting/war-and-business-kachins-frontlinehydropower-dam.

${ }^{45}$ Kachin Ranger, "Kachin Rangers Help IDPs in Kachin State," Free Burma Rangers, May 24, 2020, accessed October 15, 2020, https:// www.freeburmarangers.org/2020/05/24/kachin-rangers-help-idps-kachin-state/.

${ }^{46}$ Human Rights Activist, Interview by Author, Face to Face, Chiang Mai, June 25, 2018.

${ }^{47}$ Ibid.

${ }^{48}$ Ex-Political Prisoner, Interview by Author, Face to Face, Yangon, July 4, 2019.

49 Women's Rights Activist, Interview by Author, Face to Face, Karen State, December 3, 2018.

50 INGO Official, Interview by Author, Face to Face, Yangon, November 16, 2018.
} 
defenders and critics of the NLD government. ${ }^{51}$ As one interviewee noted, "the laws have now been established, but they are being used as a weapon of oppression." 52

Additionally, state-society relations appear to be deteriorating with the state persistently refusing to listen or cooperate with active civil society organizations. ${ }^{53}$ While this had been possible for many civil society groups during the Thein Sein era, many have found it increasingly difficult to be heard by government officials. Some of the interviewees noted that the change was merely a bureaucratic one, requiring civil society to request permission at least three days before. ${ }^{54}$ Others claimed, due to their own affiliations or lack of official registration, they were now unable to get meetings with government officials or organize workshops. ${ }^{55}$ This seemed to suggest a variable willingness by the government to engage with civil society and a civil society space that seemed to be restricting since 2015. This not only impacts freedom of expression but the ability of communities to mobilize and engage with the government on a communal platform.

\section{Changing Face: Patterns of Human Rights Abuses in Myanmar}

In recent reports by Shan and Karen civil society, there has been a documented shift in the kinds of human rights abuses committed against civilian populations. ${ }^{56}$ Previously, in periods of conflict, the majority of cases have centered around extrajudicial killings and arbitrary arrests and disappearances. Now, both communities report increasing cases of land confiscation and forced relocation. ${ }^{57}$ In Kachin, it has become the most prominent issue as the ongoing war has allowed for cronies and military elites to grab land in the name of security and development. ${ }^{58}$ The combination of displacement and land grabbing has resulted in abandoned villages being sold to the Chinese; meaning, communities having no place to return to. ${ }^{59}$ In Karen, though there is no active war, communities face similar abuses with land grabbing occurring in both ceasefire and non-ceasefire territories. As one interviewee described, "since the signing of the NCA there has been little change... because some groups are now legal, they can come and do business. One group near my village have expanded mines a lot [sic] and it is not good. It is ruining our water supply and we have many landslides; it has ruined crops and roads." 60

51 Burma Campaign UK, Myanmar Authorities Must Drop the Case Against Ko Swe Win and Decriminalise Defamation: Joint Statement, March 17, 2019, accessed October 15, 2020, https://burmacampaign.org.uk/media/ 7 March KSW FINAL ENG.pdf.

52 Yangon Based Karen Community Leader, Interview by Author, Face to Face, Mae Sot, December 12, 2018.

53 Shoon Naing and Poppy McPherson, "Lost Idol—New Wave of Myanmar Youth Activists Look Beyond Suu Kyi," Reuters, December 1, 2018, accessed October 15, 2020, https://uk.reuters.com/article/uk-myanmar-activistsidUKKCN1O02WQ.

${ }^{54}$ Justice NGO Worker, Interview by Author, Face to Face, Karen State, November 28, 2018.

${ }^{55}$ Women's Rights Activist, Interview by Author, Face to Face, Karen State, December 3, 2018.

56 “'Do Not Trespass' Land Confiscation Bu Armed Actors in Southeast Myanmar" KHRG, May 11, 2019, accessed November 16, 2020, http:// khrg.org/2019/03/18-5-nb1/do-not-trespass-land-confiscation-armed-actorssoutheast-myanmar; "Shan Communities and MPs Call for Cancellation of Dams in Conflict-Torn Northern and Southern Shan State," Shan Human Rights Foundation (SHRF), December 3, 2018, accessed October 15, 2020, http:// www.shanhumanrights.org/eng/index.php/363-shan-communities-and-mps-call-for-cancellation-of-dams-inconflict-torn-northern-and-southern-shan-state.

${ }^{57}$ KHRG, Foundation of Fear, 162-164; Shan Herald Agency for News (SHAN), "Farmers, Activists Call for NLD Govt to End Land Grabs in Shan State," Burma News International, October 31, 2016, accessed October 21, 2020, https:// www.bnionline.net/en/news/shan-state/item/2450-farmers-activists-call-for-nld-govt-to-end-land-grabs-in-shanstate.html; Richard Weir, “Nothing for Our Land': Impact of Land Confiscation on Farmers in Myanmar" (New York: Human Rights Watch, July 17, 2018), accessed October 21, 2020, https://www.hrw.org/report/2018/07/17/ nothing-our-land/impact-land-confiscation-farmers-myanmar.

${ }^{58}$ Human Rights Activist, Interview by Author, Face to Face, Chiang Mai, June 25, 2018.

59 James Nickerson, “The Kachin IDP Crisis: Myanmar's Other Humanitarian Disaster," Al Jazeera, December 2, 2018, accessed October 21, 2020, https://www.aljazeera.com/indepth/features/kachin-idp-crisis-myanmarhumanitarian-disaster-181202225600024.html.

${ }^{60}$ Community Youth Leader, Interview by Author, Face to Face, Karen State, July 9, 2019. 
This identifies a pattern of change in the methods of control and domination orchestrated by the Tatmadaw. When war and control by coercive means becomes a less viable option, such control is maintained through other more indirect forms, such as economic accumulation.

It is therefore possible to see a shift in the methods of oppression adopted and utilized by the military in relation to the borderland communities. In the junta period, society as a whole has faced a range of oppressive measures including limitations on their freedom of speech. Those communities residing within the borderlands faced additional repressive policies through the orchestration of Four Cuts and the human rights abuses that occurred because of the wars ongoing around them. These policies of oppression disproportionately impacted the lives of civilians within the borderlands causing many to be forcibly relocated or to flee to Thailand.

Yet, this relocation in itself has become part of the oppression of communities and their rights. First, the journey to relative safety held great risks due to the high density of mines in many borderland areas. ${ }^{61}$ Forty years later, many remain in camps, with dwindling supplies and even less to return for-they have been left reliant on humanitarian handouts which are increasingly drying up as more international assistance focuses on the transition in Myanmar. ${ }^{62}$ Second, as part of displacement, these communities lost access to their farms and villages and therefore, their cultural and traditional customs. A healthcare worker who grew up in one of the camps noted that few of her generation wanted to return: "They do not know Karen State, we cannot read or speak Karen, it is not our home. As we cannot farm in the camp, few would know how to make a living if we went back. We do not know our own tradition this way." 63

Consequently, communities that fled violence may have protected themselves from direct repression but are still experiencing the impacts, albeit indirectly, of such violence as well as the oppression of their cultural and traditional practices.

Since the transition began in 2008 and the ceasefire singing in 2015, there has been a substantial reduction in these directly oppressive policies that characterized the junta period. Outright violence because of war has dropped almost completely in areas where ceasefires have been signed. ${ }^{64}$ The counterinsurgency policies of the 1960 s are no longer used to try and root out dissenting forces. Nevertheless, communities within the borderlands still face higher levels of repression by state forces than those of the ethnic Barmar majority at the center of the state.

Indirect and structural violence continues to limit these communities' rights to peaceful living and accessing their human rights. Despite the ending, or freezing of armed conflicts, human rights abuses continue to be committed. Sporadic deaths and arbitrary arrests continue, as well as cases of rape conducted by Tatmadaw officers. 65 The most common abuses now center on the confiscation of land and the use of forced labor, often characterized by the state as voluntary labor carried out by villagers-laying roads, carrying heavy loads, and so forth. 66 This increase is related to the new method of control the state is imposing on the borderlands: control through economic development and state incursion into ethnic minority areas. By auctioning off traditionally held lands, many of which are resource rich, the state is reaping economic benefits, gaining access to lands and communities, and asserting control previously inaccessible to them. The consequence of such actions is creating a new wave of displacement as people attempt to move away from state control and presence due to fear of state repression.

Despite the differing situations in Karen and Kachin State, the former experiencing a reduction in violence due to the ongoing ceasefire, the latter currently an active war zone after ceasefire breakdown, economic investment is being used as a weapon of oppression in both. As

\footnotetext{
${ }^{61}$ Pedersen, Secret Genocide, 3, 103.

62 Saw Yan Naing, "Left Behind: The Karen Refugees at Mae La Camp," The Irrawaddy, April 28, 2017, accessed October 21, 2020, https:/ / www.irrawaddy.com/specials/left-behind-karen-refugees-mae-la-camp.html.

${ }^{63}$ Community Health Worker, Interview by Author, Face to Face, Yangon, July 5, 2019.

${ }^{64}$ Community Human Rights Organisation Worker, Interview by Author, Face to Face, Mae Sot, June 22, 2018.

${ }^{65}$ KHRG, Foundation of Fear, 72-74.

66 Brenner, Rebel Politics, 83-84.
} 
discussed earlier, the Kachin ceasefire broke down in 2011 over damming sites in Kachin State and the increasing presence of the Chinese investors and Tatmadaw in KIO territory. Unrest over development projects in Kachin has not diffused, with the Myitsone Dam project being permanently suspended due to civil unrest. ${ }^{67}$ Yet, fighting continues over resource-rich land such as Jade mines and land abandoned by those forced to flee, now secured through plantation projects. ${ }^{68}$ Karen interviewees noted that since the reduction in fighting in Karen as part of the ceasefire, the Tatmadaw now fought for land through land rights and access, as one put it, "they do not come with guns anymore, they come with letters." 69 Moreover, militarization in Karen is not decreasing but increasing since the ceasefire, so although there is less violence, communities do not feel safer or more secure. ${ }^{70}$

The development of the Vacant, Fallow and Virgin Land Law (VVFL) in Myanmar exemplifies how legal practice and development are being utilized to marginalize and dispossess minority populations in Myanmar's borderlands. Historically, all land is owned by the state and can be rented long term if it is registered by the land holder, this ignores all traditional land ownership within the borderlands. ${ }^{71}$ Thus, effectively dispossessing whole communities from the lands which they have resided on for generations..$^{72}$ Further, registration of land and land licenses is in the hands of village and tract administrators, as they have a say in what is termed vacant or fallow and these administrators are often corrupt or biased. ${ }^{73}$ The basis of which has left communities feeling dispossessed and helpless: "The law gives the government a lot of authority now to take our land. They have taken it, it is already sold off."

Lastly, the state and military forces are using the NCA to coercively co-opt the EAOs into the state. By promising peace and providing the space for negotiation through a multilateral framework, the transitional governments have been able to secure a further reaching end to hostilities than ever before. This has been a positive development, but actions since the establishment of the NCA have uncovered a darker side to the negotiations. Rather than developing points of agreement and commonality between those involved, recent talks have become stagnant, unable to move past the major obstacles to peace such as demobilization, disarmament, and reintegration. ${ }^{74}$ This included new directives which include a commitment to one national army and a reconfirmation of non-secession from the state. ${ }^{75}$ Such demands, even after the failure of talks to produce any definitive outcomes in past years, highlights the

${ }^{67}$ Laur Kiik, "Nationalism and Anti-Ethno-Politics: Why 'Chinese Development' Failed at Myanmar's Myitsone Dam," Eurasian Geography and Economics 57, no. 3 (May 3, 2016), 382-383, accessed October 21, 2020, https://doi.org/ $\underline{10.1080 / 15387216.2016 .1198265 .}$.

68 "Myanmar: Major Ethnic Groups and Where They Live," Al Jazeera, March 14, 2017, accessed October 21, 2020, https://www.aljazeera.com/indepth/interactive/2017/03/myanmar-major-ethnic-groupslive-170309143208539.html; "Jade and the Generals," Global Witness, May 17, 2017, accessed October 21, 2020, https:/ / www.globalwitness.org/en/campaigns/myanmar/jade-and-generals/.

${ }^{69}$ Member of Karen Refugee Council, Interview by Author, Face to Face, Mae Sot, December 12, 2018.

70 Community Human Rights Organisation Worker, Interview by Author, Face to Face, Mae Sot, June 22, 2018.

${ }^{71}$ Ben Dunant, "Why a Land Law Change is Sparking Fears of Mass Evictions," Frontier Myanmar, November 19, 2018, accessed October 21, 2020, https:// frontiermyanmar.net/en/why-a-land-law-change-is-sparking-fears-of-massevictions; Nyein Nyein, "Analysis: Rising Public Concern Over Vacant Land Law Amendment Goes Unaddressed," The Irrawaddy, February 21, 2019, accessed October 15, 2020, https://www.irrawaddy.com/ opinion/analysis/rising-public-concern-vacant-land-law-amendment-goes-unaddressed.html.

72 Jason Gelbort, "Implementation of Burma's Vacant, Fallow and Virgin Land Management Law: At Odds with the Nationwide Ceasefire Agreement and Peace Negotiations," Myanmar in Focus, December 10, 2018, accessed October 21, 2020, https://www.tni.org/en/article/implementation-of-burmas-vacant-fallow-and-virgin-landmanagement-law.

${ }^{73}$ Justice NGO Worker, Interview by Author, Face to Face, Karen State, November 28, 2018.

74 Shan, "To Hopeland and Back: The 34th Trip," Shan Herald Agency for News, December 12, 2017, accessed October 21, 2020, https://english.shannews.org/archives/16871.

75 Sai Wansai, "Myanmar's Peace Process Stagnation: Will Conditional Clause Be a Way Out?," Shan Herald Agency for News, September 12, 2018, accessed October 24, 2020, https://english.shannews.org/archives/18116. 
superiority the military continue to hold, even at the negotiating table. They are not attending to compromise; they wish to see all actors "brought into the legal fold."76

The talks and peace conferences continue to be promoted as a place of open discussion and debate with all armed actors and the support of the NLD government. This has legitimized the actions of the military and government, both domestically and internationally, as they show a commitment to peace. Consequently, it has left the EAOs in a precarious position. If they join and engage with the peace process, they risk being co-opted into a single state and army under the control of the Tatmadaw, an organization for which they have no trust. Or, should they leave or not sign, they risk losing legitimacy and support both internationally and domestically for being spoilers within the process. ${ }^{77}$ Being labelled a spoiler is a real concern as groups outside the peace process complain of pressure to join from their counterparts within the NCA, noting they are seen as stubborn and backward rather than legitimate or principled among their peers. ${ }^{78}$

\section{Legitimizing a Repressive State: Co-opting the International Community}

So far, this article has highlighted how, while the methods have changed, the state and military's attitude towards ethnic communities has remained the same. Many borderland communities continue to face high levels of repression through indirect means, leaving them few options, either to be repressed and have limited to no rights, or to leave. ${ }^{79}$ This is despite the triple transition process, that is supposedly aiming to create the idealistic peaceful, democratic, market driven state. As Myanmar is opening to the international environment, they open themselves to increasing oversight and intervention by the international community; an environment typically not conducive to continuing human rights abuses and discriminatory practices that go against the international norms. ${ }^{80}$ This section will postulate that Myanmar is minimizing such concerns through a policy of co-optation with the international community. By inviting investments through the auctioning of its globally finite natural resource deposits and large-scale infrastructure projects. It has managed to create a competitive market where investing states are more willing to overlook or negate humanitarian concerns in favor of major investment opportunities. The presence and previous dominance of investment by nations unencumbered by westernized international norms has also contributed to this position by removing the possibility of investors to place steep conditions on their investment projects.

Thein Sein's major package of economic reforms split Myanmar open to international investment after an extended period of isolationism under the junta. The introduction of competitive parliamentary elections provided a clear signpost of change to the international community, with many choosing to drop their sanctions against the state in favor of providing Overseas Development Assistance (ODA). Since the commitment by the junta to "disciplined democracy" in 2008 and the reforms of the 2011-2015 government, Myanmar's GDP has steadily grown, averaging around eight per cent per year. ${ }^{81}$ As democratic practice began to be institutionalized and reform realized, international interest and investment skyrocketed.

That is not to suggest that during its period of isolationism, both self-imposed (pre-1988) and externally enforced (post-1988), Myanmar experienced no international investment. During its isolation from the international community, many regional powers

\footnotetext{
${ }^{76}$ Ceasefire Official, Interview by Author, Face to Face, Chiang Mai, June 28, 2019.

77 Stephen John Stedman, "Spoiler Problems in Peace Processes," International Security 22, no. 2 (October 1, 1997), 8-10, accessed October 24, 2020, https:// doi.org/10.1162/isec.22.2.5.

${ }^{78}$ Kachin Activist, Interview, Face to Face, Chiang Mai, June 18, 2019.

${ }^{79}$ Hull, Everyday Politics, 10-11.

80 This increasing international oversight can be exemplified through the establishment and conduct of the UN Special Envoy to Myanmar in the wake of the Rohingya Crisis and violence in Rakhine. This envoy later extended their work to include suspected Crimes Against Humanity committed in Kachin and Karen State.

81 Nicholas Farrelly et al., "Explaining Myanmar in Flux and Transition," in Routledge Handbook of Contemporary Myanmar, ed. Adam Simpson et al. (Oxon: Routledge, 2018), 3-5.
} 
including Thailand and China invested heavily in their neighbor, though often, through unofficial methods. They benefited from the black markets along the borderlands and the ability to access the scarce resources such as teak and jade through cooperation with EAOs consequently gaining from Burma's war economy throughout the 1970s and 1980s. ${ }^{82}$ Though the brutal state repression of the 8888 pro-democracy uprising did cause international outcry and a flurry of sanctions to be levelled against the government, the impact on the economy was not as far-reaching as might have been expected. Having pursued a neutralist and isolationist discourse with the international environment, the disruption the sanctions aimed to bring to Burma's economy was perhaps not as effective as the imposers of such policies may have hoped.

Despite international sanctions, Myanmar's neighbors took an alternative approach of cautious engagement with the state. Rather, the regional powers began to invest and engage economically with the government. Japan, India, Thailand, and China all became major investors within the country's large infrastructure and border investment projects. ${ }^{83}$ As the government began to agree to numerous ceasefires throughout its borderlands, it consolidated control within such regions through economic means. ${ }^{84}$ By granting licenses to its regional investors, the State Peace and Development Council (SPDC) ${ }^{85}$ was able to extend its control in territory previously beyond its oversight while simultaneously removing revenue streams from its ethnic rivals. ${ }^{86}$ This policy of economic domination has been well documented within the ceasefires in Kachin and later Karen State. ${ }^{87}$ The success of such policies demonstrated an effective alternative to state expansion and control within the borderlands that did not require the risk of retribution and disfavor the use of direct coercive means had created.

Developing the characteristics of a democratic regime does not ensure its institutional embedding. Elections are now the primary method of state legitimation, both within authoritarian and democratic states. Increasing numbers of states are falling into the typology of a competitive authoritarianism which mixes traditionally democratic and authoritarian features into a hybrid form of governance. 88 Despite this knowledge, and the growing wariness of elections in post-war and transitioning states, the presence of elections continues to be the most notable signifier of change for many within the international environment. ${ }^{89}$ The success of the opposition to not only compete but to also win and be allowed to take power proved to be a sufficient level of development for much of the international community. From an electoral and institutional standpoint, Myanmar seemed to be achieving its transitional goals; however, as we focus on transition within the borderland, it becomes clear this is an attempt to protect the central state and military rather than truly reform.

This alteration in regime and transition toward the democratic, market-liberal and peaceful state encouraged investors from outside the region to step forward. The longstanding

\footnotetext{
82 Oh, Competing Forms of Sovereignty, 8; Robert H. Taylor, "Change in Burma: Political Demands and Military Power," Asian Affairs 22, no. 2 (June 1, 1991), 135, accessed October 24, 2020, https:/ / doi.org/10.1080/03068379108730411.

83 Core, Burma/Myanmar, 100; Turnell, Burma's Economic Transition, 482.

84 Jones, Understanding Myanmar's Ceasefires, 104; Core, Burma/Myanmar, 100.

85 The SPDC took over control of the state between 1997 and 1998 after the dissolution of the State Law and Restoration Council in late 1997. Though the some of the military elites did alter the type and overall aspect of the regime did not.

86 Lee Jones, "Explaining Myanmar's Regime Transition: The Periphery Is Central," Democratization 21, no. 5 (July 29, 2014), 792, accessed October 24, 2020, https://doi.org/10.1080/13510347.2013.863878; Jones, Understanding Myanmar's Ceasefires, 105; Oh, Competing Forms of Sovereignty, 9.

87 Renaud Egreteau, "The Burmese Jade Trail: Transnational Networks, China and the (Relative) Impact of International Sanctions on Myanmar's Gems," in Myanmar's Transition: Openings, Obstacles and Opportunities, ed. Nick Cheesman et al. (Singapore: ISEAS Publishing, 2012), 95; Jones, Understanding Myanmar's Ceasefires, 100.

88 Steven Levitsky and Lucan A. Way, "The Rise of Competitive Authoritarianism," Journal of Democracy 13, no. 2 (April 2002), 51, accessed October 24, 2020, https://doi.org/10.1353/jod.2002.0026.

89 Paul Collier, Wars, Guns and Votes: Democracy in Dangerous Places (London: Vintage, 2010), 15.
} 
sanctions programs against Myanmar's military state were eased by both the US and EU..$^{00}$ Such relaxation of sanctions has generated much needed investment in core infrastructure such as Norway's investment in Myanmar's telecommunications which aimed to see mass extension of mobile and internet infrastructure throughout Myanmar. ${ }^{91}$ This plan, and the subsequent investment in it, opened the use of mobile phones to the mass market in a way that had previously not been possible in Myanmar. Thus, the institutional transition attracted nontraditional, western investors to enter the Myanmar markets, as the minimum bars for democratization were met.

Much of the investment Myanmar now receives is focused on and within its borderland areas. These regions have remained extremely underdeveloped due to the harsh terrains, distance from the center, and the continued insecurity caused by ongoing hostilities. These regions are also the sites of many of Myanmar's natural resource deposits which remain relatively untouched. Many of the deposits Myanmar boasts within its portfolio are demanded not only on a regional level but globally and this relative abundance has Myanmar dubbed as the world's last frontier. ${ }^{92}$ As such, there is both high interest and limited supply of the resources Myanmar has for possible future investment, creating a highly competitive market for outside investment.

In addition to the resources Myanmar's land has to offer, Myanmar's lack of infrastructure and investment have proven similarly enticing to external funders. Myanmar sits on the edge of South-East Asia, along the Bay of Bengal, a location of strategic importance that has been noted since the colonial era. ${ }^{93}$ This positioning, and its proximity to regional powers China and India, have made infrastructural development of Myanmar particularly attractive to its neighbors. Notably China, Japan, and India have invested heavily in major infrastructure projects including the deep-sea ports along the coast, the Asia Highway connecting India to much of South Asia and train and gas lines from the its coast to China's interior up across Myanmar's mainland. ${ }^{94}$ This is mainly to extend and further develop the investing countries own trade routes as well as to help establish the investors stake within Myanmar and the region's infrastructure; which as we will see, has resulted in the marginalization of local communities and a minimization of the local positive externalities such investment projects have brought.

The State has granted long-term licenses to its natural resources, permitted the damming of its rivers, approved developments on its ports and transport links. Myanmar itself has been up for auction. ${ }^{95}$ Yet, the benefit of such projects and investments has had little to do with a vision of a modern Myanmar. As investment in Myanmar has increased, so has the cronyism within the state. ${ }^{96}$ The ex-Generals of Myanmar's infamous military have been able to

\footnotetext{
90 Patrick Barta and Laurence Norman, "EU to Ease Some Myanmar Sanctions," Wall Street Journal, January 23, 2012, accessed October 24, 2020, https://www.wsj.com/articles/SB10001424052970203718504577178543686051920; Engvall and Nandar Linn, Myanmar Economic Update, 162; Thomas Fuller and Paul Geitner, "European Union Suspends Sanctions on Myanmar," The New York Times, April 23, 2012, accessed October 24, 2020, https:// www.nytimes.com/2012/04/24/world/asia/eu-suspends-sanctions-on-myanmar.html.

${ }^{91}$ Nyo, Taking Stock of Myanmar's Economy, 121.

92 Edward Parker, “Myanmar's Opening: Doing Business in Asia's Final Frontier," The Diplomat, November 18, 2016, accessed October 24, 2020, https://thediplomat.com/2016/11/myanmars-opening-doing-business-in-asias-finalfrontier/.

93 Ranjit Gupta, "China, Myanmar and India: A Strategic Perspective," Indian Foreign Affairs Journal 8, no. 1 (January 2013), 80-92, accessed December 7, 2020, http://www.associationdiplomats.org/Publications/ifaj/Vol8/8.1/ ARTICLE\% 204.pdf.

94 Tun, Myanmar Signs Ceasefire.

95 Than Htike Aung, "China Inks Deal with Myanmar on 33 MoUs Including Kyaukphyu and Yangon Development Projects," Mizzima, January 19, 2020, accessed October 24, 2020, http://www.mizzima.com/article/china-inksdeal-myanmar-33-mous-including-kyaukphyu-and-yangon-development-projects.

96 Igor Blaževič, "Burma Votes for Change: The Challenges Ahead," Journal of Democracy 27, no. 2 (April 2016), 102; Turnell, Burma's Economic Transition, 110.
} 
guarantee a more than comfortable retirement through the development of partnerships with investing parties. ${ }^{97}$ Their control and worth has skyrocketed along with Myanmar's GDP and FDI figures, giving them further personal freedoms as well as increasing control over the state through alternative means; thus, helping them secure powerful positions to offset their loss of power from the junta as part of the transition.

Increased investment in Myanmar, whether it is or not skimmed off by corrupt officials, should theoretically result in some benefit to local communities through the provision of work, improved infrastructure and services. The premise that economic development can be a catalyst for change within society has led many civil society organizations to promote economic development as a method to peace. ${ }^{98}$ However, this assumes that the positive externalities from such projects permeate to the local communities around which such projects occur. Yet, the practice of implementation by the state and military within Myanmar is disrupting the diffusion of positive externalities to local communities in favor of redirection toward state-sympathetic communities and the investing partners.

Primarily, in the borderlands such as Karen state, this has been done through the resettlement and forced relocation of local populations. Since the establishment of the new regime and the signing of the NCA in 2015, direct fighting in much of the state has reduced. Yet, there have been increased accounts of land confiscation and forced portering as Tatmadaw forces clear areas for large-scale infrastructure and development projects. ${ }^{99}$ The reported land confiscation and grabbing cases for purposes of development highlight how the state is altering and utilizing its' own policies to tactically marginalize minority populations by delegitimizing their claims to the land on which they reside.

Due to the insecure environment, the Tatmadaw has effectively carved out a role for itself as defender of large-scale investment projects. Their presence and security ensure the safety and tenability of such projects for investors through guaranteeing such activities are protected from insurgents. This role of the military has licensed and legitimized their presence in areas previously inaccessible to them either through insurgent occupation or due to ceasefires with said groups. As many of the communities residing in these areas fear the military and the possibility of reprisals or human rights abuses, many will choose to flee, creating further humanitarian issues due to the increasing numbers of IDPs. ${ }^{100}$ Thus, positive externalities from such development projects cannot be realized by local communities as many flee or are forcibly relocated on the eve of such projects. Instead, communities experience the loss of livelihoods, traditional lands and customs, and are faced with increasing insecurity.

For communities that do remain in the locality of large investment projects, there is still little chance to access the benefits of development. Many are forced to work for free through forced labor by the military especially in relation to building roads and other access points. ${ }^{101}$ The military have recently defended themselves against such claims, publicizing the villagers' willingness to volunteer for such projects, though little evidence can be provided to support this claim. In many of the larger projects, especially those with regional investors, the workforce is brought in from the investing country and as such, jobs are not offered to the local

\footnotetext{
${ }^{97}$ Farrelly et al., Explaining Myanmar, 5.

98 Paul Collier, The Bottom Billion: Why the Poorest Countries Are Failing and What Can Be Done About It (New York: Oxford University Press, 2008), 186; INGO Worker, Interview, Face to Face, Chiang Mai, October 31, 2018.

99 Caroline Strover, "The Farmer Becomes the Criminal: Human Rights and Land Confiscation in Karen State," (New York: Human Rights Watch, November 3, 2016), accessed December 7, 2020, https://www.hrw.org/report/ 2016/11/03/farmer-becomes-criminal/human-rights-and-land-confiscation-karen-state.

100 Hull, Everyday Politics, 13.

101 Kim Jolliffe, "Security, Justice and Governance in South East Myanmar," (London: Saferworld, January 2019), 16, accessed October 24, 2020, https://www.saferworld.org.uk/resources/publications/1194-security-justice-andgovernance-in-south-east-myanmar-a-knowledge-attitudes-and-practices-survey-in-karen-ceasefire-areas.
} 
community. 102 Though industrialization is increasing, communities are experiencing a loss of livelihoods rather than a transformation as they are marginalized from the process.

Furthermore, for many of the projects, such as the damming of the Irrawaddy and Salween rivers to create electricity, the outputs are not intended to benefit the local community but to provide resources for the investing nation. ${ }^{103}$ This lack of benefit to the host communities has been a cause of rising tension within Myanmar, escalating so steeply that the Chinese backed Myitsone Dam project has been suspended entirely. ${ }^{104}$ Such projects therefore negatively impact communities through forced displacement, forced labor, militarization and loss of livelihoods; yet, they do not gain from the products of such large scale projects. Thus the notion of development as peace is not present in Myanmar's borderlands, it is a tool of oppression.

Local communities within Myanmar's borderlands are finding themselves under threat from the military occupation both within war and ceasefire zones. Economic development is playing a key role in ensuring the central state's increasing influence, be it hostile, within Myanmar's borderlands. The continued investment and acceptance of state strategies has legitimized the military's actions, not merely within the borderlands in this newly transitioning state but internationally. These (in)actions by the international community underline a sense of acceptance, that use of force and oppression in the name of development and modernity is an acceptable compromise when access to globally finite resources is at stake.

By opening Myanmar's borders and resources up to international investment during a period of ostensible democratic transition, the military have been able to create a competitive market for some of the world's most finite resources. The opportunity to invest on such a large scale and in some of the most lucrative industries in a state so requiring of development has proven too enticing for states once in opposition to Myanmar's regime. Now the opportunity has been offered, and the international community has not only accepted but celebrated such progress, they find themselves captured. Enticed by economic incentives that have been made attainable by a level of political change, the international opposition to Myanmar's autocratic state has crumbled. Yet, the state itself has remained, camouflaged by layers of democratic characteristics. Its actions against its minority people proves the superficiality of the changes made within the institutions of government.

As such, the international community has been effectively co-opted into compliance with the state. By creating a competitive market of investors, including regional and international powers with differing perspectives on the usefulness and appropriateness of sanctions, Myanmar has successfully positioned itself within the international economic market. ${ }^{105}$ It has been able to defend itself from the possibility of punitive actions by ensuring a backstop of alternative investors. The promotion of Myanmar as one of the last global frontiers, especially in relation to its rich natural resources, has increased the incentives for partnerships from investors that may have previously been more cautious regarding investing in such a volatile environment. ${ }^{106}$ Now committed, such investors find themselves within a system of high-stakes for disinvestment-if they do not invest, they will not get to again and the opportunity will be lost to another international investor.

For the communities that live in the villages and rural areas undergoing increased international investment, the forms of state repression they face are changing. Rather than experience the direct impact of violence from conflict related offensives and extensive counter-

\footnotetext{
102 KHRG, Foundation of Fear, 47.

103 Adam Simpson, "Challenging Hydropower Development in Myanmar (Burma): Cross-Border Activism under a Regime in Transition," The Pacific Review 26, no. 2 (May 1, 2013), 132, accessed October 24, 2020, https://doi.org/ 10.1080/09512748.2012.759264.

104 Kiik, Nationalism and Anti-Ethno-Politics, 375.

105 Justin Kent, “Myanmar, The Last Frontier?," Forbes, November 9, 2012, Online edition, accessed December 7, 2020, https:/ / www.forbes.com/sites/connorconnect/2012/11/09/myanmar-the-last-frontier/.

106 Ali Hines, “The Global Rush for Rubber: Is Myanmar the 'Final Frontier'?," Global Witness (blog), May 2, 2014, accessed December 7, 2020, https://www.globalwitness.org/en/blog/global-rush-rubber-myanmar-finalfrontier $/$.
} 
insurgency policies, they face a more indirect form of state repression. Under the new transitional state, state repression is now formed of a system of co-optation that includes incentives for both domestic and international elites, crimes against humanity related predominantly to land confiscation due to investment and development projects and continuing human rights abuses related to the presence of armed actors within these communities. These communities are left at risk of continued practices of extensive state repression that obstructs people's ability to access their basic needs, livelihoods and basic human rights.

\section{Conclusion}

Mass state repression that has been ongoing since Myanmar's independence is resulting in a "slow genocide" of its ethnic minority peoples. Through a kaleidoscope of methods, including the use of direct violence, indirect or systematic violence, and the restriction of rights and access the Myanmar state has effectively severed the ties between many communities, their livelihoods, and ways of life. Though the ongoing crimes against humanity may not result in the skyrocketing deaths per annum typically related to genocide, the forced relocation and removal of traditional lifestyles is stifling minority culture, communities and common ties. By creating environments where communities-tied to the land not only for their livelihoods but also culturally and, for many, spiritually-are either forced to move or flee from fear. Through systematic and purposeful methods, the state is creating an environment that is effectively ending a community without eliminating its members.

State oppression can take many forms and as regime type has changed within Myanmar, so too has the application of state repression against the borderlands. Under the military junta from 1962 to 2008, repressive tactics included the non-recognition of cultural and social identity; as a direct consequence of the ongoing wars, and as part of the repressive counter-insurgency strategies implemented by the state. As such, wars have been ended through ceasefire negotiation, both bilaterally and through the NCA process, and political transition has begun to take hold, the forms of state oppression have altered to match this new environment. Direct violence, typically related to wartime experiences, has dropped significantly. In its place, new, indirect forms of oppression have become the norm. The forced removal of communities from their traditional lands, alongside continued cultural repression and sporadic lapses into violence have become the new, preferred methods of the state.

By adapting to this new environment of the triple transition process, the military have succeeded in co-opting parties previously against state action. Through the development, signing and continued dialogue of the NCA, as well as the provision of financial incentives, the military and government have been able to co-opt EAOs. Through the offering of licenses, land and natural resource deposits, they have been able to co-opt those within the international environment into supporting a government undergoing transition. This leaves communities in these regions vulnerable to aggressive state policies aimed at the restriction and elimination of minority identities, by reducing the audiences and forums for them to articulate and advocate for their rights and needs.

Myanmar's triple transition process has altered the way that human rights abuses and state repression is not only carried out but also characterized; both nationally and internationally. Through the promotion of democratic characteristics and developments, coupled with the economic incentives such a resource rich country can provide, the state has been able to create a layer of protection for itself. It has co-opted national and international opposition into its systems and methods of governance including, but not limited to, its policies for the repression of minority rights and culture. In doing so, it has ensured itself the financial investment the country required to develop whilst maintaining enough institutional independence from any one investor to be able to conduct itself without concern for the investors' preferences. Though Myanmar is in need of investment, investors must also be held responsible for their roles and contributions to the legitimization of a regime that uses democratic transition not to reach any democratic ideal but to become acceptable enough to be a recipient of such projects. 


\section{Bibliography}

Al Jazeera. “Myanmar: Major Ethnic Groups and Where They Live." March 14, 2017. Accessed October 21, 2020. https://www.aljazeera.com/indepth/interactive/2017/03/ myanmar-major-ethnic-groups-live-170309143208539.html.

Aung, Than Htike. "China Inks Deal with Myanmar on 33 MoUs Including Kyaukphyu and Yangon Development Projects." Mizzima, January 19, 2020. Accessed October 24, 2020. http: / / www.mizzima.com/article/ china-inks-deal-myanmar-33-mous-includingkyaukphyu-and-yangon-development-projects.

Aung, Thu Thu. "NLD Reaffirms Priorities of Peace and Reconciliation." The Irrawaddy, September 27, 2017, Accessed October 15, 2020. https://www.irrawaddy.com/news/ burma/nld-reaffirms-priorities-peace-reconciliation.html.

Barta, Patrick, and Laurence Norman. "EU to Ease Some Myanmar Sanctions." Wall Street Journal, January 23, 2012. Accessed October 24, 2020. https://www.wsj.com/articles/ SB10001424052970203718504577178543686051920.

BBC. “Myanmar Election: Suu Kyi's NLD Wins Myanmar Landslide." November 13, 2015. Accessed October 13, 2020. http: / / www.bbc.co.uk/news/world-asia-34805806.

Blaževič, Igor. "Burma Votes for Change: The Challenges Ahead." Journal of Democracy 27, no. 2 (April 2016), 101-115.

Brenner, David. Rebel Politics: A Political Sociology of Armed Struggle in Myanmar's Borderlands. Ithaca: Cornell University Press, 2019.

Burma Campaign UK. Myanmar Authorities Must Drop the Case Against Ko Swe Win and Decriminalise Defamation: Joint Statement. March 17, 2019. Accessed October 15, 2020. https:// burmacampaign.org.uk/media/7 March KSW FINAL ENG.pdf.

Callahan, Mary P. Making Enemies: War and State Building in Burma. Ithaca: Cornell University Press, 2005.

Collier, Paul. The Bottom Billion: Why the Poorest Countries Are Failing and What Can Be Done About It. New York: Oxford University Press, 2008.

- Wars, Guns and Votes: Democracy in Dangerous Places. London: Vintage, 2010.

Core, Paul. "Burma/Myanmar: Challenges of a Ceasefire Accord in Karen State." Journal of Current Southeast Asian Affairs 28, no. 3 (October 27, 2009), 95-105.

Crouch, Melissa. The Constitution of Myanmar: A Contextual Analysis, 1st ed. Oxford: Hart Publishing, 2019.

Davies, Jack and Matthew Weaver. "Burma Election Turnout Remains Low." The Guardian, November 7, 2010. Accessed October 13, 2020. https://www.theguardian.com/world/ 2010/nov / 07 / burma-election-turnout-low.

Dittmer, Lowell. “Burma vs. Myanmar: What's in a Name?.” In Burma or Myanmar? The Struggle for National Identity, edited by Lowell Dittmer, 1-20. World Scientific, 2010.

Downing, Jared. “Myanmar 101: Burma in World War II." Frontier Myanmar, June 19, 2017. Accessed December 3, 2020. https://www.frontiermyanmar.net/en/myanmar-101burma-in-world-war-ii/.

Dunant, Ben. "Why a Land Law Change is Sparking Fears of Mass Evictions." Frontier Myanmar, November 19, 2018. Accessed October 21, 2020. https:// frontiermyanmar.net/en/why-a-land-law-change-is-sparking-fears-of-mass-evictions.

Egreteau, Renaud. Caretaking Democratization: The Military and Political Change in Myanmar. London: C Hurst \& Co, 2016.

"Patterns of Military Behavior in Myanmar's New Legislature." Asia Pacific Bulletin, No. 233. Washington, D.C.: East-West Center, September 24, 2013.

" "The Burmese Jade Trail: Transnational Networks, China and the (Relative) Impact of International Sanctions on Myanmar's Gems." In Myanmar's Transition: Openings, Obstacles and Opportunities, edited by Nick Cheesman, Monique Skidmore, and Trevor Wilson, 89-116. Singapore: ISEAS Publishing, 2012. 
Englehart, Neil A. "Is Regime Change Enough for Burma? The Problem of State Capacity." Asian Survey 45, no. 4 (August 2005), 622-644. Accessed November 15, 2020. https:// doi.org/10.1525/as.2005.45.4.622.

Engvall, Anders, Soe Nandar Linn. "Myanmar Economic Update: Macro-Economy, Fiscal Reform, and Development Options." In Debating Democratization in Myanmar, edited by Nick Cheesman, Nicholas Farrelly, and Trevor Wilson, 159-180. Singapore: ISEAS Publishing, 2014. https: / / doi.org/10.1355/9789814519151-015.

Farrelly, Nicholas, Ian Holliday, and Adam Simpson. "Explaining Myanmar in Flux and Transition." In Routledge Handbook of Contemporary Myanmar, edited by Adam Simpson, Nicholas Farrelly, and Ian Holliday, 3-12. Oxon: Routledge, 2018.

Fuller, Thomas, and Paul Geitner. "European Union Suspends Sanctions on Myanmar." The New York Times, April 23, 2012. Accessed October 24, 2020. https://www.nytimes.com/ 2012/04/24/world/asia/eu-suspends-sanctions-on-myanmar.html.

Gelbort, Jason. "Implementation of Burma's Vacant, Fallow and Virgin Land Management Law: At Odds with the Nationwide Ceasefire Agreement and Peace Negotiations." Myanmar in Focus, December 10, 2018. Accessed October 21, 2020. https://www.tni.org/en/ article/implementation-of-burmas-vacant-fallow-and-virgin-land-management-law.

Global Witness. "Guns, Cronies and Crops: How Military, Political and Business Cronies Conspired to Grab Land in Myanmar." March 26, 2015. Accessed November 15, 2020. https://www.globalwitness.org/en/campaigns/land-deals/guns-cronies-and-crops/.

------. "Jade and the Generals." May 17, 2017. Accessed October 21, 2020. https:// www.globalwitness.org/en/campaigns/myanmar/jade-and-generals/.

Gupta, Ranjit. "China, Myanmar and India: A Strategic Perspective." Indian Foreign Affairs Journal 8, no. 1 (January 2013), 80-92.

Hines, Ali. "The Global Gold Rush for Rubber: Is Myanmar the 'Final Frontier'?" Global Witness (blog). May 2, 2014. Accessed December 7, 2020. https:// www.globalwitness.org/en/blog/global-rush-rubber-myanmar-final-frontier/.

Hull, Stephen. "The 'Everyday Politics' of IDP Protection in Karen State." Journal of Current Southeast Asian Affairs 28, no. 2 (July 29, 2009), 7-21.

Jolliffe, Kim. "Security, Justice and Governance in South East Myanmar." London: SaferWorld, January 2019. Accessed October 24, 2020. https://www.saferworld.org.uk/resources/ publications / 1194-security-justice-and-governance-in-south-east-myanmar-aknowledge-attitudes-and-practices-survey-in-karen-ceasefire-areas.

Jones, Lee. "Explaining Myanmar's Regime Transition: The Periphery Is Central." Democratization 21, no. 5 (July 29, 2014), 780-802. Accessed October 24, 2020. https:// doi.org/10.1080/13510347.2013.863878.

. “Understanding Myanmar's Ceasefires: Geopolitics, Political Economy and StateBuilding." In War and Peace in the Borderlands of Myanmar: The Kachin Ceasefire, 19942011, edited by Mandy Sadan, 95-113. Copenhagen: NIAS Press, 2016.

Kachin Ranger. "Kachin Rangers Help IDPs in Kachin State." Free Burma Rangers, May 24, 2020. Accessed October 15, 2020. https://www.freeburmarangers.org/2020/05/24/kachinrangers-help-idps-kachin-state/.

Karen Human Rights Group (KHRG). “'Do Not Trespass' Land Confiscation By Armed Actors in Southeast Myanmar." May 11, 2019. Accessed November 16, 2020. http://khrg.org/ 2019/03/18-5-nb1/do-not-trespass-land-confiscation-armed-actors-southeast-myanmar.

--------. Foundation of Fear: 25 Years of Villagers' Voices from Southeast Myanmar. Myanmar: Karen Human Rights Group, October 2017. Accessed October 13, 2020. https://reliefweb.int/ report/myanmar/foundation-fear-25-years-villagers-voices-southeast-myanmar.

Kent, Justin. "Myanmar, The Last Frontier?." Forbes, November 9, 2012. Online edition. Accessed December 7, 2020. https://www.forbes.com/sites/connorconnect/ 2012/11/09/myanmar-the-last-frontier/. 
Kiik, Laur. "Nationalism and Anti-Ethno-Politics: Why 'Chinese Development' Failed at Myanmar's Myitsone Dam." Eurasian Geography and Economics 57, no. 3 (May 3, 2016), 374-402. Accessed October 21, 2020. https: / / doi.org/10.1080/15387216.2016.1198265.

Lall, Marie, and Ashley South. "Comparing Models of Non-State Ethnic Education in Myanmar: The Mon and Karen National Education Regimes." Journal of Contemporary Asia 44, no. 2 (April 3, 2014), 298-321. Accessed October 13, 2020. https://doi.org/ $10.1080 / 00472336.2013 .823534$.

Levitsky, Steven, and Lucan A. Way. "The Rise of Competitive Authoritarianism." Journal of Democracy 13, no. 2 (April 2002), 51-65. Accessed October 24, 2020. https://doi.org/ 10.1353/jod.2002.0026.

Liu, Zhentu. "Tracking Myanmar's Public Procurement Reform." World Economic Forum, February 9, 2015. Accessed October 13, 2020. https://www.weforum.org/agenda/ 2015/02/tracking-myanmars-public-procurement-reform/.

McPherson, Poppy. “No Vote, No Candidates: Myanmar's Muslims Barred from Their Own Election." The Guardian, November 3, 2015. Accessed October 13, 2020. https:// www.theguardian.com/world/2015/nov/03/no-vote-no-candidates-myanmarsmuslims-barred-from-their-own-election.

Min Mang, Lun. "Dismay over NCA-Signatories Growing." The Myanmar Times, January 12, 2018. Accessed October 15, 2020. https:// www.mmtimes.com/news/dismay-over-ncasignatories-growing.html.

Mon, Ye. "UEC Cancels Voting in Two More Shan Townships." The Myanmar Times, October 28, 2015. Accessed October 13, 2020. https://www.mmtimes.com/national-news/17226uec-cancels-voting-in-two-more-shan-townships.html.

Mon, Ye, Thomas Kean, and Hkun Lat. "War and Business: Kachin's 'Frontline' Hydropower Dam." Frontier Myanmar, July 29, 2019, Accessed October 15, 2020. https:// pulitzercenter.org/reporting/war-and-business-kachins-frontline-hydropower-dam.

Naing, Saw Yan. "Left Behind: The Karen Refugees at Mae La Camp." The Irrawaddy, April 28, 2017. Accessed October 21, 2020. https://www.irrawaddy.com/specials/left-behindkaren-refugees-mae-la-camp.html.

Naing, Shoon, and Poppy McPherson. "Lost Idol-New Wave of Myanmar Youth Activists Look Beyond Suu Kyi." Reuters, December 1, 2018. Accessed October 15, 2020. https:// uk.reuters.com/article/uk-myanmar-activists-idUKKCN1O02WQ.

Nickerson, James. "The Kachin IDP Crisis: Myanmar's Other Humanitarian Disaster." $A l$ Jazeera, December 2, 2018. Accessed October 21, 2020. https://www.aljazeera.com/ indepth/features/kachin-idp-crisis-myanmar-humanitariandisaster-181202225600024.html.

Nyein, Nyein. "Analysis: Rising Public Concern Over Vacant Land Law Amendment Goes Unaddressed." The Irrawaddy, February 21, 2019. Accessed October 15, 2020. https:// www.irrawaddy.com/opinion/analysis/rising-public-concern-vacant-land-lawamendment-goes-unaddressed.html.

. "Analysis: Why Did the KNU Temporarily Leave Peace Talks?." The Irrawaddy, October 29, 2018. Accessed October 15, 2020. https://www.irrawaddy.com/factiva/analysisknu-temporarily-leave-peace-talks.html.

Nyo, Khin Maung. "Taking Stock of Myanmar's Economy in 2011." In Myanmar's Transition: Openings, Obstacles and Opportunities, edited by Nick Cheesman, Monique Skidmore, and Trevor Wilson, 119-136. Singapore: ISEAS Publishing, 2012. https://doi.org/ 10.1355/9789814414173-014.

Oh, Su-Ann. "Competing Forms of Sovereignty in the Karen State of Myanmar." Singapore: ISEAS Working Paper No. 1, 2013, 1-23.

Oo, Min Zaw. "Understanding Myanmar's Peace Process: Ceasefire Agreements." Catalizing Reflection 2 Myanmar: Swisspeace, 2014, 1-44. Accessed December 3, 2020. https:// www.swisspeace.ch/fileadmin/user upload/Media/Publications/ Catalyzing_Reflections 22014 online.pdf. 
Parker, Edward. "Myanmar's Opening: Doing Business in Asia's Final Frontier." The Diplomat, November 18, 2016. Accessed October 24, 2020. https://thediplomat.com/2016/11/ myanmars-opening-doing-business-in-asias-final-frontier/.

Pedersen, Daniel. Secret Genocide: Voices Of The Karen Of Burma. Dunboyne: Maverick House, 2011.

Plunkett, Anna. "A Glimmer of Hope for Burma's Peace Process?." Strife (blog), 2018. Accessed October 15, 2020. http://www.strifeblog.org/2018/03/27/a-glimmer-of-hope-forburmas-peace-process /.

Sadan, Mandy, ed. War and Peace in the Borderlands of Myanmar: The Kachin Ceasefire, 1994-2011. Copenhagen: NIAS Press, 2016.

Selth, Andrew. "All Going According to Plan?: The Armed Forces and Government in Myanmar." Contemporary Southeast Asia: A Journal of International and Strategic Affairs 40, no. 1 (April 2018), 1-26.

. "Burma: A Strategic Perspective." Working Paper Series. Japan: The Asia Foundation, May 2001.

Shan Herald Agency for News (SHAN). "Farmers, Activists Call for NLD Govt to End Land Grabs in Shan State." Burma News International, October 31, 2016. Accessed October 21, 2020. https://www.bnionline.net/en/news/shan-state/item/2450-farmers-activistscall-for-nld-govt-to-end-land-grabs-in-shan-state.html.

“To Hopeland and Back: The 34th Trip." December 12, 2017. Accessed October 21, 2020. https:/ / english.shannews.org/archives/16871.

Shan Human Rights Foundation (SHRF). "Shan Communities and MPs Call for Cancellation of Dams in Conflict-Torn Northern and Southern Shan State." December 3, 2018. Accessed October 15, 2020. http://www.shanhumanrights.org/eng/index.php/363-shancommunities-and-mps-call-for-cancellation-of-dams-in-conflict-torn-northern-andsouthern-shan-state.

Simpson, Adam. "Challenging Hydropower Development in Myanmar (Burma): Cross-Border Activism under a Regime in Transition." The Pacific Review 26, no. 2 (May 1, 2013), 129152. Accessed October 24, 2020. https:// doi.org/10.1080/09512748.2012.759264.

South, Ashley. "Protecting Civilians in the Kachin Borderlands, Myanmar: Key Threats and Local Responses." Humanitarian Policy Group (HPG) Working Paper 4. Overseas Development Institute, London, 2018. Accessed October 15, 2020. https:// www.odi.org/sites/odi.org.uk/files/resource-documents/12566.pdf.

. "Burma's Longest War: Anatomy of the Karen Conflict." Special Reports. Amsterdam: Transnational Institute. March 2011. Accessed December 3, 2020. https://www.tni.org/ en/briefing/burmas-longest-war-anatomy-karen-conflict.

Stedman, Stephen John. "Spoiler Problems in Peace Processes." International Security 22, no. 2 (October 1, 1997), 5-53. Accessed October 24, 2020. https://doi.org/10.1162/isec.22.2.5.

Strover, Caroline. "The Farmer Becomes the Criminal: Human Rights and Land Confiscation in Karen State." New York: Human Rights Watch, November 3, 2016. Accessed December 7, 2020. https://www.hrw.org/report/2016/11/03/farmer-becomescriminal/human-rights-and-land-confiscation-karen-state.

Taylor, Robert H., "Change in Burma: Political Demands and Military Power." Asian Affairs 22, no. 2 (June 1, 1991), 131-141. Accessed October 24, 2020. https://doi.org/ $10.1080 / 03068379108730411$.

Tun, Soe Zeya. "Myanmar Signs Ceasefire to End 62-Year Ethnic Conflict." Reuters, January 12, 2012. Accessed October 13, 2020. https://www.reuters.com/article/us-myanmarethnic-idUSTRE80B0EX20120112.

Turnell, Sean. "Burma's Economic Transition: Hopes and Hurdles." Social Research 82, no. 2 (Summer 2015), 481-506.

Wansai, Sai. "Myanmar's Peace Process Stagnation: Will Conditional Clause Be a Way Out?" Shan Herald Agency for News, September 12, 2018. Accessed October 24, 2020. https:// english.shannews.org/archives/18116. 
Weir, Richard. "'Nothing for Our Land': Impact of Land Confiscation on Farmers in Myanmar." New York: Human Rights Watch, July 17, 2018. Accessed October 21, 2020. https:// www.hrw.org/report/2018/07/17/nothing-our-land/impact-land-confiscationfarmers-myanmar.

World Bank. “World Bank Prepares Interim Strategy Note for Myanmar.” August 10, 2012. Accessed October 5, 2020. http:// www.worldbank.org/en/news/feature/2012/08/10/ world-bank-prepares-interim-strategy-note-for-myanmar.

Zarni, Maung, and Alice Cowley. "The Slow-Burning Genocide of Myanmar's Rohingya." Pacific Rim Law \& Policy Journal 23, no. 3 (2014), 681-752. 